\title{
Modo comunicativo utilizado por crianças com síndrome de Down***
}

\author{
Communicative profile used by children with Down Syndrome
}

\author{
Eliza Porto-Cunha* \\ Suelly Cecilia Olivan Limongi**
}

*Fonoaudióloga. Especialização em Psicologia da Infância pela Universidade Federal de São Paulo. Fonoaudióloga da Prefeitura Municipal de Itapevi. Endereço: Rua Cipotânea, 51 - Cidade Universitária - São Paulo SP - CEP 05360-160 (portoeliza@usp.br).

**Fonoaudióloga. Professora Livre Docente do Curso de Fonoaudiologia da Faculdade de Medicina da Universidade de São Paulo. Coordenadora do Laboratório de Investigação Fonoaudiológica em Síndromes e Alterações SensórioMotoras da Faculdade de Medicina da Universidade de São Paulo.

***Trabalho Realizado no Laboratório de Investigação Fonoaudiológica em Síndromes e Alterações SensórioMotoras da Faculdade de Medicina da Universidade de São Paulo.

Artigo Original de Pesquisa

Artigo Submetido a Avaliação por Pares

Conflito de Interesse: não

Recebido em 02.04.2008. Revisado em 05.09.2008. Aceito para Publicação em 21.10.2008.

\begin{abstract}
Background: the communication of children with Down syndrome (DS) is frequently impaired due to difficulties in the phonological, syntactic and semantic aspects of language. In order to compensate these difficulties, many children use gestures for a longer period of time than children who present typical development (TD). Aim: to verify the performance of children with DS regarding their communicative profile (verbal, oral and gestural) during a play situation and a spontaneous interaction with an adult. Method: 28 children with DS were studied in two different play situations: with a speech-language therapist and with the adult caregiver. Pragmatic theories were usede to analyse the data. To determine the statistical significance of the results, the statistical tests of Kruskal-Wallis, Mann-Whitney and Wilcoxon and the confidence interval were used with a significance of 5\%. Results: the verbal communication mean was used mostly during the interaction with the caregivers and the gestural communication mean was used mostly during the interaction with the therapists. Conclusion: considering that the verbal communication mean is the one which is socially more used, the play situation with the caregiver was the most effective. However, although less verbal communicative acts were produced during the interaction with the speech-language therapist, the child used gestures to communicate, that is, the lack or little verbal communication did not stop the child from communicating with the interlocutor. Key Words: Down Syndrome; Language Development; Communication.
\end{abstract}

\section{Resumo}

Tema: a comunicação das crianças com síndrome de Down (SD) é muitas vezes prejudicada devido a dificuldades nos aspectos fonológico, sintático e semântico da linguagem. Para compensar essas dificuldades, muitas crianças utilizam os gestos por um tempo mais prolongado do que as crianças com desenvolvimento típico (DT). Objetivo: verificar o desempenho de crianças com SD no que diz respeito ao modo comunicativo (verbal, vocal e gestual) utilizado na interação espontânea com um adulto em situação de brincadeira. Método: 28 crianças com SD foram estudadas em duas situações distintas: brincadeira com o terapeuta e brincadeira com o cuidador. Foram consideradas as teorias pragmáticas para análise dos resultados. Para determinar a significância estatística foram usados os testes Kuskal-Wallis, Mann-Whitney e Wilcoxon e determinado o nível de significância em 5\%. Resultado: houve maior utilização do meio comunicativo verbal na interação com o cuidador e do meio gestual na interação com o terapeuta. Conclusão: considerando que o meio comunicativo mais utilizado socialmente é o verbal, podemos considerar que a comunicação, nesse ponto de vista, foi mais efetiva na situação de brincadeira com o cuidador. No entanto, embora tenham sido produzidos menos atos comunicativos verbais na interação com o terapeuta, a criança utilizou o gesto para se comunicar, ou seja, a falta ou pouca comunicação verbal não impediu que a criança se comunicasse com seu interlocutor.

Palavras-Chave: Síndrome de Down; Desenvolvimento da Linguagem; Comunicação.

Referenciar este material como:

- Porto-Cunha E, Limongi SCO. Communicative profile used by children with Down Syndrome (original title: Modo comunicativo utilizado por crianças com ב 3 síndrome de Down). Pró-Fono Revista de Atualização Científica. 2008 out-dez;20(4):243-8. 


\section{Introduction}

Several researchers have reported that children with Down syndrome (DS) usually present well developed gestural skills in order to compensate the deficits in oral language and speech intelligibility, since they can be more easily understood when communicating by gestures than by oral language 1-2.

The use of communicative gestures accompanied by speech is observed in typically developing children (TD) from the end of sensorimotor and beginning of pre-operational period, according to Piaget's studies 3 . In children with DS, gestural communication develops as well as observed in TD children. However, deictic gestures are noticed for a longer time period in these children and continue to be used simultaneously to symbolic gestures1. Children with DS keep using gestures for an extended period of time, adjusting them according to the environment context with the purpose to be more easily comprehended by the interlocutor 1-2, 4-8.

The mother-child interaction should be considered as an important source of cognitive and linguistic stimuli during this period 9-16. The lack of adequate stimuli during mother-child with DS interaction may be harmful to child's development, in view of the fact that the mother is the main mediator between the child and the environment.

Fernandes 17 suggests that language should be studied taking into account its social value. In that sense, pragmatics theories are useful since they propose the inclusion of context's aspects in language study, therefore considering the relation between language and context 17 .

The aim of the present study was to verify the performance of children with DS concerning the use of communicative means (verbal, vocal and gestural) during interaction with an adult in a free play situation.

\section{Method}

The consent form was signed by subjects' legal tutors in order to participate in this study. The present research was approved by the Ethics Committee for the Analysis of Research Protocols (CAPPesq) of the Clinics Hospital of The School of Medicine of the University of Sao Paulo (838/05).

Participated in this study 28 children with DS, who attended speech-language therapy at the Speech-Language Pathology Laboratory in
Syndromes and Sensorimotor Deficits (SLPL - SSD) of the School of Medicine of the University of Sao Paulo.

The inclusion criteria for subjects' selection were as follows: DS diagnosis, audiologic and pediatric regular follow ups, age range between two and eight years old, be placed at the end of sensorimotor or beginning of preoperational periods of cognitive development, and be subjected to speech-language therapeutic process based on dialectic-didactic method 18. As exclusion criteria: presence of other associated pathologies and/or congenital heart disease with surgical indication.

The subjects were arranged in four age groups, considering their chronological age, since although they share the same cognitive developmental phase, the chronological age aspect could interfere with child's performance (G1 - nine children with ages ranging from 2:0 to 3:5 years; G2 - six children with ages ranging from $3: 6$ to $4: 11$ years; $\mathrm{G} 3$ - seven children with ages ranging from 5:0 and 6:5 years; G4 - six children with ages ranging from 6:6 to 8:0 years).

Children from G1 were placed in the end of sensorimotor period and children from the other groups were placed in the beginning of preoperational period of cognitive development. In order to obtain children's cognitive development level, the cognitive assessment was carried out according to specific protocol 19.

All children were studied in two free play spontaneous situations with a predetermined set of appropriate toys according to children's developmental stage.

Children's play with the adult was recorded individually in video in two sessions (30 minutes each), comprising the following situations: (A) interaction with therapist and (B) interaction with caregiver. In situation A, children played with their therapist. In situation B, the caregiver was considered as some family member or person who usually takes the child to speech-language therapy and who received all the directions and information concerning both speech-language treatment process and child's language and communication development.

The same set of toys was used in both situations. The toys were given in a closed box to the adult and he or she was told to play with the children in an informal way.

The interaction situations were recorded in the therapy room of the SLPL - SSD, which was arranged at the same way it used to be during therapy sessions, that is, a thin mattress in the floor or a set of small table and chair.

The interval between A and B situations' recording 
was at least one week and at most one month. The sequence for recording $\mathrm{A}$ and $\mathrm{B}$ situations was randomly determined.

The communicative means used by children were analyzed from data gathered from their communicative functional profile, which was obtained based on the previously proposed model 20.

The proposed classification for communicative means was as follows: Verbal Mean (VE): when child's oral production comprises at least $75 \%$ of Brazilian Portuguese phonemes; Vocal Mean (VO): the other oral productions; and Gestural Mean $(\mathrm{G})$ : all communicative acts that evolve body and facial movements.

For data analysis, 15 from the 30 minutes of childadult interaction were transcribed 21 , using a specific protocol 20.

In order to determine results' statistical significance, Kruskal-Wallis, Mann-Whitney and Wilcoxon non parametric statistical tests were administered. Confidence Interval technique for the mean was employed for descriptive analysis complementation and the significance level adopted was $0,05(5 \%)$.

\section{Resultados}

Situation A

Table 1 shows the percentage means of VE presented by children from the four age groups, when interacting with their therapist. Based on the $\mathrm{p}$-value $(\mathrm{p}=0,019)$, it can be observed that there were significant differences among the groups.

The analysis between group pairs shows that this difference was significant only between $\mathrm{G} 1$ and G4 (p-value $=0,004)$. The oldest children (G4) produced in average $46 \%$ of $\mathrm{VE}$, whereas the youngest children (G1) produced only $2,39 \%$. The intermediate groups (G2 and G3) did not show differences of statistical significance when compared to the other groups, as well as when compared to each other.

No significant difference was found between groups concerning VO and $\mathrm{G}$ (see Table 1). However, it can be observed that the use of gestures has progressively decreased with age (G1 $=79,93 \%, \mathrm{G} 2$ $=74,08 \%, \mathrm{G} 3=67,4 \%$ e G4 $=46,20 \%)$. Concerning $\mathrm{VO}$, no significant changes with age were observed.
Situation B

Considering child-caregiver interaction situation (Table 2), significant differences were observed among the groups concerning the use of $\mathrm{VE}$ ( $\mathrm{p}$-value $=0,003$ ). The analysis between group pairs evidenced that this difference was significant for comparisons between $\mathrm{G} 1$ and the other groups $(\mathrm{G} 2: \mathrm{p}=0,019 ; \mathrm{G} 3: \mathrm{p}=0,005 ; \mathrm{G} 4: \mathrm{p}=0,002)$. These results suggest that the youngest children produced significantly fewer verbalizations $(\mathrm{G} 1=$ $13,39 \%)$ than did older children from the other groups $(\mathrm{G} 2=35,37 \%, \mathrm{G} 3=29,91 \%, \mathrm{G} 4=57,45 \%)$.

Differences among groups were also observed concerning the use of $\mathrm{G}$ (p-value $=0,012)$. The group pair analysis demonstrated that this difference was determined by differences between $\mathrm{G} 1$ and the other groups $(\mathrm{G} 2$ : $\mathrm{p}=0,034 ; \mathrm{G} 3$ : $\mathrm{p}=0,050 ; \mathrm{G} 4: \mathrm{p}=0,007)$ and between $\mathrm{G} 4$ and $\mathrm{G} 3(\mathrm{p}=0,046)$.

These findings suggest that the youngest children (G1) used significantly more gestures (76\%) than did older children from the other groups $(\mathrm{G} 2=$ $53,57 \%, \mathrm{G} 3=54,40 \%, \mathrm{G} 4=37,92 \%$ ).

It can be observed the increase of VE use with age, except for a slight decrease presented for G3, when compared to G2. It can be also verified the decrease of VO and G use with age, except for a slight increase of VO use by G3, when compared to G2.

Comparison between A and B situations

When DS children's performance in A and B situations were compared (Graphic 1), it could be observed that there were statistically significant differences concerning the use of VE for G2 $(\mathrm{p}=0,043), \mathrm{G} 3(\mathrm{p}=0,028)$, and $\mathrm{G} 4(\mathrm{p}=0,028)$. The three groups presented higher use of verbalizations in situation B than in situation A, that is, the subjects presented higher use of VE when interacting with caregivers than when interacting with therapists.

Concerning VO, statistically significant difference was found between $\mathrm{A}$ and $\mathrm{B}$ situations only for G1 $(p=0,015)$, with higher use of vocalizations in situation $B$.

Regarding the use of gestures, children with DS presented higher use of $G$ in situation $A$ than in situation B. It was observed for $\mathrm{G} 2(\mathrm{p}=0,046), \mathrm{G} 3$ $(\mathrm{p}=0,028)$ and $\mathrm{G} 4(\mathrm{p}=0,046)$. 
TABLE 1. Communicative Mean used by children with DS on different age ranges in situation A.

\begin{tabular}{ccccccccccc}
\hline & \multicolumn{4}{c}{ Verbal Mean } & \multicolumn{3}{c}{ Vocal Mean } & \multicolumn{3}{c}{ Gestural Mean } \\
\hline & N & $\begin{array}{c}\text { Mean } \\
\text { \% }\end{array}$ & Median & SD & $\begin{array}{c}\text { Mean } \\
\text { Gean }\end{array}$ & Median & SD & $\%$ & Median & SD \\
\hline G1 & 9 & 2,39 & 1,2 & 3,31 & 31,4 & 34,7 & 17,95 & 79,93 & 81,4 & 19,29 \\
G2 & 6 & 19,97 & 12,05 & 23,27 & 27,07 & 29,3 & 16,61 & 74,08 & 75,45 & 20,48 \\
G3 & 7 & 25,49 & 4,9 & 29,05 & 25,41 & 19,4 & 12,96 & 67,4 & 66,7 & 21,32 \\
G4 & 6 & 46 & 55,2 & 24,34 & 30,97 & 30,05 & 23,69 & 46,2 & 41,35 & 21,24 \\
\hline p- & & & & & & & & & \\
\end{tabular}

value $\quad 0,019 * \quad 0,905 \quad 0,052 \#$

* statistically significant p-value, considering the adopted significance level.

\# p-value near to significance limit, showing tendency to a significant result.

SD: standard deviation

TABLE 2. Communicative Mean used by children with DS on different age ranges in situation $B$.

\begin{tabular}{ccccccccccc}
\hline & \multicolumn{3}{c}{ Verbal Mean } & \multicolumn{3}{c}{ Vocal Mean } & \multicolumn{3}{c}{ Gestural Mean } \\
\hline & $\mathrm{N}$ & $\begin{array}{c}\text { Mean } \\
\%\end{array}$ & Median & SD & $\begin{array}{c}\text { Mean } \\
\text { Gean }\end{array}$ & Median & SD & $\%$ & Median & SD \\
\hline G1 & 9 & 1,39 & 0,65 & 2,37 & 50,34 & 51,85 & 18,4 & 76 & 73,6 & 10,38 \\
G2 & 6 & 35,37 & 34,25 & 36,18 & 31,15 & 21,1 & 25,44 & 53,57 & 48,1 & 25,71 \\
G3 & 7 & 29,91 & 12,4 & 30,37 & 37,91 & 50,6 & 27,26 & 54,4 & 53,6 & 16,81 \\
G4 & 6 & 57,45 & 66,9 & 30,29 & 22,3 & 20,55 & 16,68 & 37,92 & 33 & 19,78 \\
\hline p-value & & $0,003 *$ & & & 0,151 & & & 0,012 & \\
\hline
\end{tabular}

* statistically significant $p$-value, considering the adopted significance level.

\# p-value near to significance limit, showing tendency to a significant result.

SD: standard deviation

GRAPHIC1. Percentages means comparisons concerning Communicative Means used by groups in A and B situations.

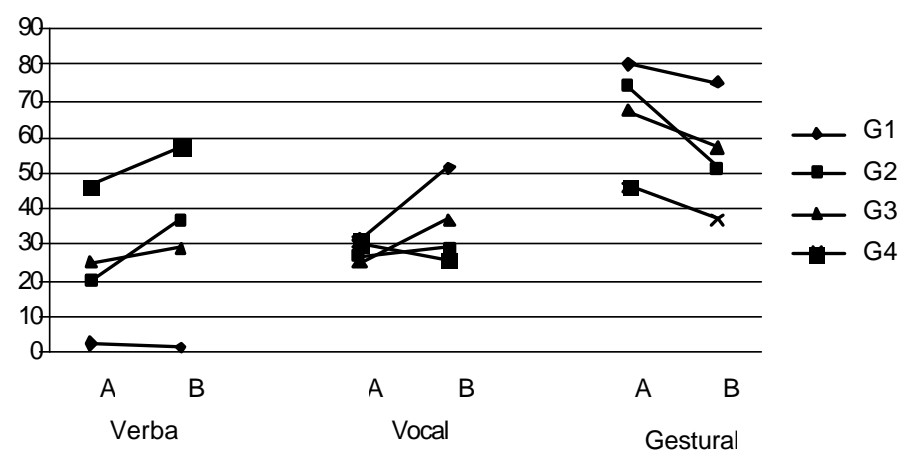

\section{Discussion}

In child- therapist interaction situation, children from G4 presented higher use of VE when compared to G1 and there were no statistically significant differences between groups concerning VO and G. However, although no significant results were found between groups concerning the use of $\mathrm{G}$, we can observe its progressive decrease with age.

These results are consistent with literature, which points out that children with DS follow the same process of language and cognitive development observed in TD children, but in a slower and delayed way 6-7, 19, 22-23. In the present study, we found that the youngest children presented lower use of VE when compared to the oldest ones, such as observed in TD children.

Although a mild decrease has been observed concerning the use of gestures with age and despite verbal communication increase, there were no significant differences between age groups for gestural communicative mean. Literature shows that some children with DS keep using gestures for a longer time period, in order to compensate the deficits in oral language 1-2, 4-8, 24. This can explain the fact that the use of $\mathrm{G}$ didn't decreased with age and with the increase of VE.

No differences between groups were observed 
concerning the use of $\mathrm{VO}$, what can be due to the fact that the productions with less than $75 \%$ of Brazilian Portuguese phonemes were considered VO 20. As described in literature, children with DS generally present speech intelligibility because of stomatognathic system impairment combined with comprehension deficits and difficulties on learning grammatical and syntactic rules $2,8,25$. Thus, children with DS usually present oral productions composed by less than $75 \%$ of intelligible phonemes, characterizing vocal productions.

Results showed that during the play situation with caregiver, children from G1 presented significantly fewer verbal communicative acts than did the other groups. As observed in situation A, the use of verbal mean increased as the children got older.

The analysis of the use of gestural communicative acts indicated that in situation B, there were significant differences among groups. Children from G1 produced significantly more gestures than did children from the other groups. The difference between situations $\mathrm{A}$ and $\mathrm{B}$ concerning the use of gestural communicative mean may be due to the context changing. Some authors have argued that children with DS use gestures for an extended period of time, adjusting them according to the environment context 1-2, 4-8, therefore demonstrating that the lack of verbal intelligibility don't hinder children's communicative attempts.

When the two situations were compared, it was observed higher use of VE by children from G2, G3

\section{References}

1. Franco F, Wishart JG. Use of pointing and other gestures by young children with Down syndrome. American Journal on Mental Retardation. 1995 Sep 100(2):160-82.

2. Chan JB, Iacono T. Gesture and production in children with Down syndrome. AAC Augmentative and Alternative Communication. 2001 Jun 17(2):73-87.

3. Piaget J. A formação do símbolo na criança. Rio de Janeiro: Zahar; 1978. Edição original de 1946.

4. Iverson JM, Caselli MC. From communication to language in two modalities. Cognitive Development. 1994 Jan-Mar 9(1):23-43.

5. Clibbens J. Signing and lexical development in children with Down syndrome. Down Syndrome Research and Practice. 2001 Sep-Dec 7(3):101-5.

6. Miles S, Chapman RS. Narrative content as described by individuals with Down's syndrome and typically developing children. Journal of Speech, Language, and Hearing Research. 2002 Fev 45(1):175-89. and $\mathrm{G} 4$ in situation $\mathrm{B}$ and higher use of $\mathrm{G}$ in situation A. Given that the use of gestures for a prolonged period of time is explained by speech intelligibility $1-2,4,7-8$ and that gestures serve as a device to assure message comprehension by the interlocutor, the higher use of gestures by children in situation $A$ is justified for the lower use of verbal communicative acts. The two situations considered in this study were chosen for language assessment of children with DS, given the importance of family and family dynamics on language development 10 16.

\section{Conclusion}

Based on data analysis and its discussion, it is possible to conclude that:

. the comparison of the two studied situations evidenced different characteristics of DS children's communication concerning the use of communication means. Considering that the verbal mean is the most socially used communicative mean, we can speculate from this point of view that communication was more effective during playing with caregivers' situation (situation B);

. regarding the studied population, it's important to consider that although there were observed fewer verbal communicative acts in the situation A (playing with therapist), children used gestures to communicate, that is, the lack or absence of verbal communication did not hindered children's communication with their therapist.
7. Iverson JM, Longobardi E, Caselli MC. Relationship between gestures and words in children with Down syndrome and typically developing children in the early stages of communicative development. Int J Lang Commun Disord. 2003 Apr-Jun 38(2):179-97.

8. Iverson JM, Goldin-Meadow S. Gesture paves the way for language development. Psychol Sci. 2005 May 16(5):367-71.

9. Gomes RCG, Andrade RV, Limongi SCO. Trabalho de orientação fonoaudiológica a mães de crianças com síndrome de Down (0 a 3 anos): estudo clínico de dois casos. Pró-Fono Revista de Atualização Científica. 1992 Out-Dez 4(2):22-8.

10. Cahill BM, Glidden LM. Influence of child diagnosis on family and parental functioning: Down syndrome versus other disabilities. American Journal on Mental Retardation. 1996 Sep 101:149-60. 
11. Hauser-Cram P, Warfield ME, Shonkoff JP, Krauss MW, Upshur CC, Sayer A. Family influences on adaptive development in young children with Down syndrome. Child Development. 1999 Jul-Ago 70(4):979-89.

12. Limongi SCO, Andrade RV, Lima FAGF, Alabarse VM, Perez VM. Processo terapêutico fonoaudiológico realizado com um par de gêmeos portadores da síndrome de Down. Pró-Fono Revista de Atualização Científica. 2000 Jan 12(1):24-33.

13 - Pino O. The effect of context on mother's interaction style with Down's syndrome and typically developing children. Reseach Development Disabilit. 2000 Sep-Out 21(15):329-46.

14. Andrade RV, Limongi SCO. O processo terapêutico fonoaudiológico de crianças pequenas portadoras de síndrome de Down e a orientação à família. Revista da Sociedade Brasileira de Fonoaudiologia. 2001 Abr-Jun 6(2):29-33.

15. Ricci LA, Hodapp RM. Fathers of children with Down's syndrome versus other types of intellectual disability: perceptions, stress and involvement. J. Intellectt. Disabil. Res. 2003 May-Jun 47(4-5):273-84.

16. Johnson-Glenberg MC, Chapman RS. Predictors of parent-child language during novel task play: a comparison between typically developing children and individuals whit Down syndrome. Journal of Intellectual Disability Research. 2004 Mar 48(3):225-38.

17. Fernandes FDM. Autismo infantil: repensando o enfoque fonoaudiológico: aspectos funcionais da comunicação. São Paulo: Lovise, 1996.
18. Parrat-Dayan S. Procesos internos y externos en la construcción de una explicación causal. In: Assis MC; Assis OZM; Ramozzi-Chiarottino Z. orgs. Piaget: Teoria e Prática. Campinas: Proepe, 1996. p. 28-45.

19. Limongi SCO, Carvallo RMM, Souza ER. Auditory processing and language in Down syndrome. Journal of Medical in Speech-Language Pathology. 2000 Mar 8(1):2734.

20. Fernandes FDM. Pragmática. In: Andrade CRF, BefiLopes DM, Fernandes FDM, Wertzner H. editores. ABFW: Teste de linguagem infantil nas áreas de fonologia, vocabulário, fluência e pragmática. Barueri (SP): Pró-Fono, 2004. cap; 4. p. 83-97.

21. Porto E, Santos IG, Limongi SCO, Fernandes FDM. Amostra de filmagem e análise da pragmática em crianças com síndrome de Down. Pró-Fono Revista de Atualização Científica. 2007 Abr-Jun 19(2):159-66.

22. Laws G, Bishop DVM. Pragmatic language impairment and social deficits in Williams syndrome: a comparison with Down's syndrome and specific language impairment. Int. J. Lang. Comm. Dis. 2004 Jan-Mar 39(1):45-64.

23. Andrade RV, Limongi SCO. A emergência da comunicação expressiva na criança com síndrome de Down. Pró-Fono: Revista de Atualização Científica. 2007 SetDez 19(4):387-92.

24. Limongi SCO, Mendes AE, Carvalho AMA, Val DC do, Andrade RV. A relação comunicação não verbal-verbal na síndrome de Down. Revista da Sociedade Brasileira de Fonoaudiologia. 2006 Ago-Out 11(3):135-41.

25. Porto E, Pereira T, Margall SAC. Análise da produção articulatória e dos processos fonológicos realizados por crianças portadoras da síndrome de Down. Pró-Fono Revista de Atualização Científica. 2000 Jan 12(1):34-9. 